\title{
Binding of Fibrinogen to Human Monocytes
}

Dario C. Altieri, Pier Mannuccio Mannucci, and Anna M. Capitanio

Angelo Bianchi Bonomi Hemophilia and Thrombosis Centre and Institute of Internal Medicine, University of Milano and Maggiore Hospital, 20122 Milan, Italy

\begin{abstract}
The interaction of fibrinogen with monocytes was studied. After stimulation with ADP $(10 \mu \mathrm{M})$ or thrombin $(1 \mathrm{U} / \mathrm{ml})$, plateletfree suspensions of human monocytes bind ${ }^{125} \mathrm{I}$-fibrinogen with two different affinities in a specific and $\mathrm{Ca}^{2+}$-dependent reaction with saturation at $5.80-7.35 \times 10^{-7} \mathrm{M}$ of added protein. The binding of fibrinogen to specific receptors on monocytes induces the procoagulant activity of these cells. Thrombasthenic cells or normal monocytes preincubated with a monoclonal antibody to the platelet glycoprotein IIb/IIIa complex (10E5) do not bind fibrinogen and have no procoagulant activity. Metabolic studies with $\left[{ }^{35}\right.$ S $]$ methionine revealed that cultured monocytes actually synthesize a surface antigen precipitated by $10 \mathrm{E5}$ antibody as a major band with 92,000 relative molecular weight. Our data indicate that monocytes express receptors for fibrinogen only in part related to the platelet glycoprotein IIb/IIIa complex. Furthermore, the binding of fibrinogen to monocytes enhances the cooperation of these cells in hemostasis.
\end{abstract}

\section{Introduction}

Human monocytes have many different functions in the immune response. These cells mediate the scavenging of tissues and body fluids $(1,2)$, humoral cooperation with peripheral lymphocytes $(3,4)$ and antibody-dependent cellular cytotoxicity (5). Moreover, monocytes widely interact with the hemostatic system. Procoagulant activity (PCA) ${ }^{1}$ after stimulation with several agents (6-11), membrane binding of plasma coagulation factors (12), association of fibrin to the cell surface (13-15), ability to synthesize and secrete fibronectin (16) or thrombospondin (17) are indications of the important participation of monocytes in coagulation. There have also been reports indicating that the glycoprotein IIb/IIIa complex (GP IIb/IIIa complex), a receptor for fibrinogen on platelets (18-23), is also present on normal

A preliminary report of this work was presented at the 10th International Congress on Thrombosis and Hemostasis, San Diego, CA, 14-19 July 1985, and published in abstract form (1985. Thromb. Hemostasis. 54: 170).

Address reprint requests to Dr. Altieri, Hemophilia and Thrombosis Centre, Via Pace 9, 20122 Milan, Italy.

Received for publication 29 October 1985 and in revised form 24 June 1986.

1. Abbreviations used in this paper: DTT, dithiothreitol; GP IIb/IIIa, glycoprotein IIb/IIIa; PBMC, peripheral blood mononuclear cells; PCA, procoagulant activity; PMSF, phenylmethylsulphonyl fluoride; vWF, von Willebrand factor.

J. Clin. Invest.

(c) The American Society for Clinical Investigation, Inc.

0021-9738/86/10/0968/09 \$1.00

Volume 78, October 1986, 968-976 monocytes (24-26) but not on either cell in Glanzmann's thrombasthenia $(25,26)$, but these observations have recently been challenged $(27,28)$. We now show that normal monocytes synthesize receptors for fibrinogen, functionally similar to but not identical with the platelet GP IIb/IIIa complex and, furthermore, that fibrinogen binding to monocytes is necessary for PCA.

\section{Methods}

\section{Materials}

Plastic, sterile disposable syringes, pipettes, and petri dishes $(60 \mathrm{~mm} \phi)$ were from Falcon Labware Division (Becton Dickinson Co., Oxnard, CA). Sterile pyrogen-free water was from Travenol Laboratories (Rome, Italy). Micro-Eppendorf tubes were from Sarstedt (Nümbrecht, Federal Republic of Germany). EDTA, disodium salt, was from Carlo Erba, Milan, Italy. Bovine serum albumin (fraction V) (BSA), 2-dithiothreitol (DTT), $\alpha$-naphthyl acetate esterase, sodium ADP, E-toxate (Limulus amebocyte lysate) for detection and semiquantitation of endotoxin were obtained from Sigma Chemical Co. (St. Louis, MO). Heparin was from Roche (Liquemin, Basel, Switzerland). 25\% glutaraldehyde solution for electron microscopy and Triton X-100 were from BDH Chemicals Ltd. (Poole, UK). Lymphoprep (1.077 $d$ ) was from Nyegaard (Oslo, Norway). Hepes, minimum essential medium (MEM)/Eagle methionine and glutamine free and RPMI 1640 tissue culture medium were from Flow Laboratories (Irvine, Ayrshire, UK); Versene $(1: 5,000)$ from Eurobio (Paris, France). Antibiotic-antimycotic mixture containing penicillin $10,000 \mathrm{U} / \mathrm{ml}$, fungizone $25 \mu \mathrm{g} / \mathrm{ml}$ and streptomycin $10,000 \mu \mathrm{g} / \mathrm{ml}$, was from GIBCO (Grand Island, NY). Acrylamide, $N$ - $N$-methylene-bisacrylamide, sodium dodecyl sulfate (SDS), Tris, Coomassie Brilliant Blue R 250, and molecular weight standards were from Bio-Rad Laboratories (Richmond, CA). Nonidet P-40 was obtained from Particle Data Inc. (Elmhurst, IL). $\alpha$-Thrombin was a gift from Dr. J. Fenton (Albany, NY). Hirudin was purchased from Pentapharma (Basel, Switzerland) and dissolved in sterile water. Potato apyrase was prepared as described by Molnar and Lorand (29). Phenylmethylsulfonyl fluoride (PMSF) was from Calbiochem-Behring Corp. (La Jolla, CA). 1,3,4,6-Tetrachloro-3a,6a diphenylglycoluril (Iodogen) was from Pierce Chemical Co. (Rockford, IL). [ ${ }^{125}$ I]Sodium iodide, carrier free, was from Amersham International (Buckingamshire, UK). $\left.{ }^{35} \mathrm{~S}\right]$ Methionine $(1,100 \mathrm{Ci} / \mathrm{mmol})$ was from $\mathrm{New}$ England Nuclear (DuPont de Nemours, Dreieich, Federal Republic of Germany). Protein A Sepharose CL 4B and Sepharose G 25 coarse were from Pharmacia Fine Chemicals (Uppsala, Sweden). Methyl-silicone oil (DC 200) and hi-phenyl silicone oil (DC 550) were from Nye Inc. Specialty Lubricants (New Bedford, MA). A working mixture of silicone oil was prepared before use in ratio of 1 part DC 200 to 8 parts DC 550. Human brain thromboplastin (a gift from Dr. L. Poller) was from Manchester Comparative Reagents (Manchester, England). Factors XII-, IX- and Vdeficient plasmas were from congenitally deficient patients. Factors VIIand X-deficient plasmas were from General Diagnostic (Warner Lambert, Morris Plains, NJ).

\section{Procedures}

Preparation of cells. Peripheral blood mononuclear cells (PBMC) were isolated by the method of Bøyum (30). $120 \mathrm{ml}$ of blood, obtained after informed consent from drug free healthy donors, were drawn in plastic syringes, anticoagulated with heparin $(10 \mathrm{U} / 60 \mathrm{ml})$ and centrifuged at 
$120 \mathrm{~g}$ for $15 \mathrm{~min}$ at room temperature $\left(20-25^{\circ} \mathrm{C}\right)$. The platelet-rich plasma was discarded and the pelleted erythrocytes and mononuclear cells were resuspended and diluted with an equal volume of cold 0.14 $\mathrm{M}$ phosphate buffered-saline (PBS), $\mathrm{pH}$ 7.4. $35 \mathrm{ml}$ were layered onto 15 $\mathrm{ml}$ of Lymphoprep in 50-ml polypropylene conical tubes and centrifuged at $400 \mathrm{~g}$ for $\mathbf{4 0} \mathrm{min}$ at room temperature. The cells at the interface were carefully removed with sterile plastic pipettes; were washed two times with excess $5 \mathrm{mM}$ PBS-EDTA, centrifuged once at $400 \mathrm{~g}$ for $20 \mathrm{~min}$ at $4^{\circ} \mathrm{C}$, then once at $120 \mathrm{~g}$ for $12 \mathrm{~min}$ at $4^{\circ} \mathrm{C}$ to remove further platelet contaminants; a last wash with EDTA-free buffer was also centrifuged at $120 \mathrm{~g}$ for $12 \mathrm{~min}$ at $4^{\circ} \mathrm{C}$. To obtain platelet-free suspensions of monocytes, in addition to adding EDTA to the washing buffer, we removed platelets adhering to monocytes by the method of Pawlowski et al. (31). Briefly, suspensions of PBMC were incubated twice at $37^{\circ} \mathrm{C}$ for $15 \mathrm{~min}$ in autologous serum supplemented with $5 \mathrm{mM}$ EDTA. Cells were then recovered by centrifugation at $400 \mathrm{~g}$ for $15 \mathrm{~min}$ at room temperature and resuspended in RPMI 1640 medium containing $50 \mathrm{U} / \mathrm{ml}$ penicillin, $0.125 \mathrm{ng} / \mathrm{ml}$ fungizone, and $50 \mu \mathrm{g} / \mathrm{ml}$ streptomycin plus $10 \%$ autologous serum to give $8 \times 10^{6} \mathrm{cells} / \mathrm{ml}$. Autologous serum was prepared by allowing the blood to clot in plastic tubes at $37^{\circ} \mathrm{C}$ for at least $120 \mathrm{~min}$ and centrifugation at $3,200 \mathrm{~g}$ for $15 \mathrm{~min}$ at room temperature. Human monocytes were separated by PBMC as described by Fischer et al. (32). Briefly, $5 \mathrm{ml}$ of the purified mononuclear cell suspension $\left(8 \times 10^{6} / \mathrm{ml}\right)$ were layered on each precoated plate and incubated at $37^{\circ} \mathrm{C}$ for $60 \mathrm{~min}$ in an incubator. At the end of the incubation, the medium, containing mainly lymphocytes, was removed and used for lymphocyte preparations. The plates were rinsed with four to five rapid changes of RPMI 1640 prewarmed to $37^{\circ} \mathrm{C}$. $4 \mathrm{ml}$ of Versene were added and after a 15-min incubation at room temperature, $1 \mathrm{ml}$ of autologous serum was added and the loosely adherent monocytes were scraped off with a rubber policeman. Monocytes from several plates were pooled, centrifuged at 400 $g$ for $10 \mathrm{~min}$ at $4^{\circ} \mathrm{C}$ and resuspended in RPMI 1640 containing $10 \%$ of autologous serum to give $1.5 \times 10^{7} \mathrm{cells} / \mathrm{ml}$. Cells were kept at $4^{\circ} \mathrm{C}$ until ready to use. The purity of the monocyte preparations obtained in this way was $>90 \%$, as assessed by $\alpha$-naphthyl acetate esterase staining and the viability was $>95 \%$ as judged by trypan blue exclusion. Strictly aseptic conditions were used to preserve sterility during each step of the cell isolation procedures. With these precautions, the Limulus amebocyte lysate assay for detection of endotoxin contaminant in monocyte cultures isolated as described above gave $<0.1 \mathrm{ng} / \mathrm{ml}$ of endotoxin, with $0.1 \mathrm{ng} /$ $\mathrm{ml}$ as lower limit of the method.

Purified monocyte preparations were also obtained from two patients with Glanzmann's thrombasthenia type 1 . These patients have been described in previous publications $(33,34)$ and fulfill all the accepted criteria for diagnosis.

Platelet isolation and labeling. Washed human platelets were prepared by the method of Mustard et al. (35) from freshly collected blood anticoagulated with acid citrate/dextrose. Platelets were counted by phase contrast microscopy and diluted to $4 \times 10^{8} / \mathrm{ml}$ in Tyrode's albumin buffer $\mathrm{pH}$ 7.35. In labeling experiments, washed platelets were suspended in Hepes buffer containing $3.8 \mathrm{mM}$ Hepes, $3.8 \mathrm{mM} \mathrm{NaH}_{2} \mathrm{PO}_{4}, 0.137 \mathrm{M}$ $\mathrm{NaCl}, 2.7 \mathrm{mM} \mathrm{KCl}, 1 \mathrm{mM} \mathrm{MgCl} 2$ and $0.01 \%$ dextrose, $\mathrm{pH} 7.35 .1 \mathrm{ml}$ of platelet suspension $\left(4 \times 10^{8} / \mathrm{ml}\right)$ was iodinated by the Iodogen method, as described by Tuszynski et al. (36).

Electron microscopy studies. Several monocyte preparations were studied by electron microscopy to detect adherent platelets or fragments of platelets surrounding the cell surface. Aliquots $(0.3 \mathrm{ml})$ of monocyte suspensions were adjusted to $0.7-1 \times 10^{7} / \mathrm{ml}$ in RPMI 1640 containing $10 \%$ of autologous serum. Cells were fixed in $2.5 \%$ glutaraldehyde in 0.1 $\mathrm{M}$ phosphate buffer, $\mathrm{pH} 7.3$, and centrifuged at $400 \mathrm{~g}$ for $15 \mathrm{~min}$ at $4^{\circ} \mathrm{C}$. The pellet obtained was stored at $4^{\circ} \mathrm{C}$ until use.

Protein purification and labeling. Fibrinogen, purified from human plasma by the glycine precipitation method (37) and $90-95 \%$ clottable was radiolabeled with ${ }^{125} \mathrm{I}$ by the Iodogen method (38). Typically, 170 $\mu \mathrm{g}$ of Iodogen in $170 \mu \mathrm{l}$ of dichloromethane were dried in the bottom of a glass tube; $200 \mu \mathrm{l}$ of fibrinogen $(5 \mathrm{mg} / \mathrm{ml})$ resuspended in $0.055 \mathrm{M}$ sodium citrate buffer, $\mathrm{pH} 7.4$, were placed in the tube and $700 \mu \mathrm{Ci}(7$ $\mu$ l) of carrier-free sodium [ $\left.{ }^{125} \mathrm{I}\right]$ iodide added. After $20 \mathrm{~min}$ of incubation on ice with occasional agitation, the solution was removed from the tube and gel filtered on a Sepharose G-25 coarse column $(100 \times 2.5 \mathrm{~cm})$ equilibrated with $0.055 \mathrm{M}$ sodium citrate buffer, $\mathrm{pH}$ 7.4. Specific activity of ${ }^{125}$ I-fibrinogen ranged from 4.5 to $8 \times 10^{5} \mathrm{cpm} / \mu \mathrm{g}$.

Human von Willebrand factor (vWF) was purified as described by De Marco and Shapiro (39) and was radiolabeled with ${ }^{125}$ I by the Iodogen method. Specific activity of ${ }^{125} \mathrm{I}-\mathrm{vWF}$ was $3.2 \times 10^{5} \mathrm{cpm} / \mu \mathrm{g}$. Human purified fibronectin was a gift from Dr. Cutolo (Rheumatological Center, Genoa University, Genoa, Italy).

${ }^{125}$ I-Fibrinogen binding to human monocytes. The ability of normal or thrombasthenic monocytes to bind fibrinogen was investigated as follows. In a typical experiment, aliquots $(0.2 \mathrm{ml})$ of monocyte suspension $\left(1.5 \times 10^{7} / \mathrm{ml}\right)$ were incubated at room temperature with $1 \mathrm{U} / \mathrm{ml}$ thrombin or $10 \mu \mathrm{M}$ ADP in the presence of $1 \mathrm{mM} \mathrm{CaCl}_{2}$. After $1 \mathrm{~min}$ incubation, $5 \mathrm{U} / \mathrm{ml}$ hirudin were added and the mixture incubated at room temperature in the presence of ${ }^{125} \mathrm{I}$-fibrinogen $\left(6 \times 10^{-8} \mathrm{M}\right)$. No differences were observed when the incubation of monocytes with ADP was prolonged to $15 \mathrm{~min}$ at room temperature. In all experiments, the final volume was adjusted to $0.35 \mathrm{ml}$ with RPMI 1640 .

Similar incubations were also performed at $4^{\circ} \mathrm{C}$ or at $37^{\circ} \mathrm{C}$. The amount of ${ }^{125} \mathrm{I}$-fibrinogen bound to monocytes was measured at selected time intervals between 1 and $60 \mathrm{~min}$. At the end of each interval, after gentle resuspension, $0.3-\mathrm{ml}$ portions were layered onto $50 \mu \mathrm{l}$ of silicone oil in $0.5 \mathrm{ml}$ micro-Eppendorf tubes and free and monocyte-bound fibrinogen were separated by centrifugation at $12,000 \mathrm{~g}$ for $2 \mathrm{~min}$ at room temperature in an Eppendorf 5414 centrifuge. Specific binding was calculated by subtracting from the total the amount of fibrinogen bound in the presence of a 50-fold excess of unlabeled fibrinogen added to the monocyte suspension at the start of the incubation (nonspecific binding). Nonspecific binding varied from 20 to $30 \%$ of the total. When the competitive inhibition by fibrinogen, vWF or fibronectin of labeled fibrinogen binding to monocytes was evaluated, $7.3 \times 10^{-7} \mathrm{M}$ of fibrinogen or 250 $\mu \mathrm{g} / \mathrm{ml}$ of $\mathrm{vWF}$ or fibronectin were incubated with monocytes before the addition of concentrations of ${ }^{125} \mathrm{I}$-fibrinogen ranging from 0.14 to 1.47 $\times 10^{-7} \mathrm{M}$.

To define the role of $\mathrm{Ca}^{2+}$ ions in fibrinogen binding to monocytes, aliquots $(0.2 \mathrm{ml})$ of monocyte suspension were preincubated with 10 mM EDTA for $1 \mathrm{~min}$ before the addition of the stimulants. For doseresponse studies, $0.2-\mathrm{ml}$ aliquots of monocyte suspension were incubated in a final volume of $0.35 \mathrm{ml}$ with $1 \mathrm{U} / \mathrm{ml}$ thrombin or $10 \mu \mathrm{M}$ ADP in the presence of $1 \mathrm{mM} \mathrm{CaCl}$. After the addition of $5 \mathrm{U} / \mathrm{ml}$ hirudin, increasing concentrations $\left(0.03-8.80 \times 10^{-7} \mathrm{M}\right)$ of ${ }^{125}$ I-fibrinogen were added and fibrinogen binding to monocytes was determined 15 min later as described above. Radioactivity in pellet and supernatant were measured in a gammacounter (model 1260, LKB, Bromma, Sweden).

${ }^{125} \mathrm{I-vWF}$ binding to monocytes. Aliquots $(0.2 \mathrm{ml})$ of monocyte suspension were stimulated with thrombin $(1 \mathrm{U} / \mathrm{ml})$ for $1 \mathrm{~min}$ at room temperature in the presence of $1 \mathrm{mM} \mathrm{CaCl}$. After the addition of 5 $\mathrm{U} / \mathrm{ml}$ hirudin, the mixture was incubated with various concentrations $(2-75 \mu \mathrm{g} / \mathrm{ml})$ of ${ }^{125} \mathrm{I}-\mathrm{vWF}$. ${ }^{125} \mathrm{I}-\mathrm{vWF}$ binding to monocytes was determined after $15 \mathrm{~min}$ by the same procedures described for the fibrinogen binding studies. Nonspecific binding was determined in the presence of a 50 75-fold excess of unlabeled vWF preincubated with the monocytes.

${ }^{125}$ I-10E5 Monoclonal antibody binding to monocytes. Aliquots of the murine monoclonal antibody 10E5 that precipitates the platelet GP IIb/IIIa complex, previously characterized (40) and kindly supplied by Dr. B. S. Coller (SUNY, Stony Brook, NY) were radiolabeled with ${ }^{125} \mathrm{I}$ by the chloramine $\mathrm{T}$ method (41). The specific activity of ${ }^{125} \mathrm{I}-10 \mathrm{E} 5$ antibody was $1.3 \times 10^{7} \mathrm{cpm} / \mu \mathrm{g}$. Aliquots $(0.2 \mathrm{ml})$ of normal or thrombasthenic monocyte suspensions were incubated with or without stimulus for $5 \mathrm{~min}$ at room temperature with ${ }^{125} \mathrm{I}-10 \mathrm{E} 5$ antibody (concentrations $0.2-4.5 \mu \mathrm{g} / \mathrm{ml}$ ) and the extent of ${ }^{125} \mathrm{I}-10 \mathrm{E} 5$ antibody binding determined. Nonspecific binding was measured in the presence of a 50-fold excess of unlabeled antibody preincubated with the monocytes, and accounted for $2 \%$ of the maximal total binding.

Immunoprecipitation of monocyte membrane protein. Isolated monocytes $\left(7 \times 10^{7} / \mathrm{ml}\right)$ or washed platelets $\left(4 \times 10^{8} / \mathrm{ml}\right)$ were iodinated by the Iodogen method (36). After three washes in Hepes buffer $\mathrm{pH} 7.35$, 
the pellet was resuspended for $30 \mathrm{~min}$ at $4^{\circ} \mathrm{C}$ in $1 \mathrm{ml}$ of lysis buffer containing $1 \%$ Nonidet $\mathrm{P}-40,0.5 \%$ Triton X-100, $0.05 \mathrm{M}$ Tris- $\mathrm{HCl}, 0.15$ $\mathrm{M} \mathrm{NaCl}, 0.1 \% \mathrm{BSA}, 0.001 \mathrm{M}$ PMSF, pH 8.3. At the end of the incubation the lysate was centrifuged at $12,000 \mathrm{~g}$ for $10 \mathrm{~min}$ and the supernatant was collected. Immunoprecipitation studies were carried out as described previously (42) with the following modifications. Aliquots of the platelet or monocyte lysate were incubated with $70 \mu \mathrm{g} / \mathrm{ml}$ of $10 \mathrm{E} 5$ antibody for $18 \mathrm{~h}$ at $4^{\circ} \mathrm{C} .25 \mu \mathrm{l}$ of protein A Sepharose CL $4 B(0.2 \mathrm{~g} / \mathrm{ml})$ were then added and the incubation continued for additional $6 \mathrm{~h}$ at $4^{\circ} \mathrm{C}$. After extensive washing with $0.14 \mathrm{M} \mathrm{PBS,} \mathrm{pH} \mathrm{7.4,} \mathrm{the} \mathrm{immunoprecipitate} \mathrm{was}$ solubilized in 3\% SDS, reduced with $0.2 \mathrm{M}$ DTT, and boiled for $5 \mathrm{~min}$ at $100^{\circ} \mathrm{C}$ to release the bound antigen and antibody. The supernatant obtained after centrifugation at $12,000 \mathrm{~g}$ for $5 \mathrm{~min}$ was electrophoresed on a 7.5\% SDS polyacrylamide gel, as described by Laemmli (43). Comparative molecular weight standards run with each sample were myosin, 200,000 relative mol wt; $\beta$-galactosidase, 116,000 relative mol wt; phosphorylase B, 92,500 relative mol wt; BSA, 66,200 relative mol wt; and ovalbumin, 45,000 relative mol wt. The gels were fixed, stained with Coomassie Brilliant Blue, destained, dried and exposed for autoradiography between a x-ray film (3M Corp., St. Paul, MN) and an intensifying screen (Cronex, E. I. DuPont de Nemours, Wilmington, DE) for $7 \mathrm{~d}$ at $-70^{\circ} \mathrm{C}$.

Metabolic labeling of monocytes. The following experiments were carried out to determine whether the monocyte surface component involved in fibrinogen binding was synthesized during active cell metabolism. Human monocytes were isolated as described above under strict sterility and resuspended at the concentration of $6 \times 10^{6} / \mathrm{ml}$ in methionine-free minimal essential medium supplemented with $1 \% \mathrm{~L}$-glutamine, $100 \mu \mathrm{g} / \mathrm{ml}$ streptomycin, $100 \mathrm{U} / \mathrm{ml}$ penicillin, and $10 \%$ autologous serum (prepared after extensive dialysis against methionine-free minimal essential medium). $400 \mu \mathrm{Ci} / \mathrm{ml}$ of $\left[{ }^{35} \mathrm{~S}\right]$ methionine was then added and the cells were cultured at $37^{\circ} \mathrm{C}$ in a $5 \% \mathrm{CO}_{2}$ humidified incubator for $12 \mathrm{~h}$. At the end of the incubation, the cells were harvested, washed three times with $0.14 \mathrm{M}$ PBS pH 7.4 and resuspended in $0.5 \mathrm{ml}$ of lysis buffer for $30 \mathrm{~min}$ at $4^{\circ} \mathrm{C}$, as described above. Immunoprecipitation studies of monocytes pulse-labeled with $\left[{ }^{35} \mathrm{~S}\right]$ methionine were performed with $10 \mathrm{E} 5$ antibody as described in the preceding paragraph.

PCA induced by monocytes. Monocyte PCA has been evaluated as described by Kornberg et al. (44). Suspensions of normal or thrombasthenic monocytes, stimulated to induce fibrinogen binding, were tested for their ability to shorten the clotting time of normal human plasma in a one-stage plasma recalcification time test. Aliquots $(0.2 \mathrm{ml})$ of normal or thrombasthenic monocytes $\left(1.5 \times 10^{7} / \mathrm{ml}\right)$ resuspended in RPMI 1640 without serum were incubated with $10 \mu \mathrm{M}$ ADP in the presence of 1 $\mathrm{mM} \mathrm{CaCl}_{2}$. At the end of the incubation, $0.1-\mathrm{ml}$ aliquots of the mixture were transferred into glass tubes and incubated at $37^{\circ} \mathrm{C}$ for $1 \mathrm{~min}$ with $0.1 \mathrm{ml}$ of plasma obtained from 10 normal donors. $0.1 \mathrm{ml}$ of $0.025 \mathrm{M}$ $\mathrm{CaCl}_{2}$ was then added and the clotting time read.

In some experiments, the ability of ADP-stimulated normal monocytes to shorten the recalcification time of plasmas deficient in various coagulation factors was evaluated. Factor V-, VII-, IX-, X-, and XIIdeficient plasmas were tested with various monocyte preparations. To explore whether soluble factors released by monocytes were involved in the expression of PCA, suspensions of ADP-stimulated normal monocytes were centrifuged at $12,000 \mathrm{~g}$ for $15 \mathrm{~min}$ at room temperature. $0.1 \mathrm{ml}$ of the supernatant was tested for its ability to shorten the normal human plasma recalcification time. Control experiments were performed with unstimulated monocytes $\left(1.5 \times 10^{7} / \mathrm{ml}\right)$, with unstimulated or ADPstimulated lymphocytes $\left(1.5 \times 10^{7} / \mathrm{ml}\right)$, human platelets $\left(4 \times 10^{8} / \mathrm{ml}\right)$ or RPMI 1640. Units of PCA were determined by comparison of the plasma clotting time induced by serial dilutions of a standard human brain thromboplastin. A clotting time of $22 \mathrm{~s}$ (dilution 1:64) was arbitrarily designated as equivalent to $100 \mathrm{U}$ of PCA.

Inhibition of ${ }^{125}$ I-fibrinogen binding and PCA of monocytes. 20 $\mu \mathrm{g} / \mathrm{ml}$ of $10 \mathrm{E} 5$ antibody were incubated with thrombin $(1 \mathrm{U} / \mathrm{ml})-$ or ADP $(10 \mu \mathrm{M})$-stimulated monocyte suspensions at room temperature. After $5 \mathrm{~min},{ }^{125}$ I-fibrinogen $\left(0.03-8.80 \times 10^{-7} \mathrm{M}\right)$ was added and the extent of fibrinogen binding assayed as described above. Inhibition of monocyte PCA by 10E5 antibody was studied by incubating $0.3 \mathrm{ml}$ of monocyte suspensions at room temperature for $5 \mathrm{~min}$ with $20 \mu \mathrm{g} / \mathrm{ml}$ of $10 \mathrm{E} 5$ antibody. ADP $(10 \mu \mathrm{M})$ was then added, in the presence of $\mathrm{CaCl}_{2}$ $(1 \mathrm{mM})$, and the mixture incubated at room temperature for an additional 10 min. PCA generation of these monocytes treated with $10 \mathrm{E} 5$ antibody was assessed as described above.

Protein concentration. Protein concentration was calculated from the absorbance at $280 \mathrm{~nm}$, using extinction coefficients of 1.51 for fibrinogen, 1.97 for fibronectin, 1.4 for 10E5 antibody, and 1.23 for vWF.

Analysis of data. To calculate the number of fibrinogen and 10E5 antibody binding sites on monocytes and the relative dissociation constants $\left(K_{\mathrm{d}}\right)$, the value of specific binding was plotted by the method of Scatchard (45) and analyzed by the method of Feldman (46). Competitive inhibition by fibrinogen, fibronectin or vWF of ${ }^{125} \mathrm{I}$-fibrinogen binding to monocytes was calculated from the Lineweaver-Burk double reciprocal plot (47)

\section{Results}

Purity of the monocyte suspension. Several experiments were carried out to evaluate whether or not the monocyte preparations were free of platelet contamination. First, aliquots of washed normal autologous platelets $\left(4 \times 10^{8} / \mathrm{ml}\right)$ labeled with ${ }^{125} \mathrm{I}$ were added to the freshly collected blood. At the end of the cell isolation procedures, $<0.1 \%$ of the platelet-associated radioactivity was found in the final monocyte suspension. Second, to investigate the effects of low levels of platelet contaminant on the monocyte response to fibrinogen, we added aliquots of washed platelets in the monocyte preparation in a ratio of 5:100 platelets/ monocytes. Under these conditions, the interaction of monocytes with fibrinogen did not differ from that of controls without platelets (not shown). Furthermore, aliquots of normal platelets were added to the whole blood of a patient with Glanzmann's thrombasthenia. The lack of ${ }^{125}$ I-fibrinogen interaction with suspensions of thrombasthenic monocytes further confirmed that all normal platelets exogenously added had been removed during the cell washing procedures. Monocytes were also characterized morphologically. In phase-contrast microscopy there were no free platelets in the monocyte suspensions prepared as described above. Finally, electron microscopy provided evidence that there were neither intact nor disrupted platelets nor fragments of membranes adhering to the monocyte surface (Fig. 1).

${ }^{125}$ I-Fibrinogen binding to human monocytes. Unstimulated monocytes, like unstimulated or thrombin- or ADP-stimulated lymphocytes did not specifically bind ${ }^{125}$ I-fibrinogen. In contrast, after stimulation with thrombin or ADP, suspensions of normal human monocytes at room temperature bound ${ }^{125}$ I-fibrinogen in a time-dependent reaction which reached equilibrium within 15-20 min (Fig. 2). Preincubation of stimulated monocytes with a 50-fold excess of unlabeled fibrinogen resulted in 70 to $80 \%$ inhibition of ${ }^{125}$ I-fibrinogen binding to monocytes, while excess ovalbumin or intact IgG had no effect. Inhibition of fibrinogen binding by 70 to $80 \%$ was also achieved by preincubation of the cell suspension with $10 \mathrm{mM}$ EDTA. The addition of a 50fold excess of unlabeled fibrinogen at equilibrium induced displacement of $>60 \%$ of the radioligand bound (Fig. 2).

The rate of fibrinogen binding in the incubation mixture was found to be directly related to the concentration of monocytes $\left(0.5-2 \times 10^{7} / \mathrm{ml}\right)$ and it was optimal when $1.5 \times 10^{7}$ cells/ $\mathrm{ml}$ are used. Little difference was observed between experiments performed at room temperature or at $37^{\circ} \mathrm{C}$, but ${ }^{125} \mathrm{I}$-fibrinogen binding to monocytes was considerably reduced at $4^{\circ} \mathrm{C}$ (not shown).

Binding of labeled fibrinogen to stimulated monocytes was studied quantitatively by incubating monocyte suspensions with 

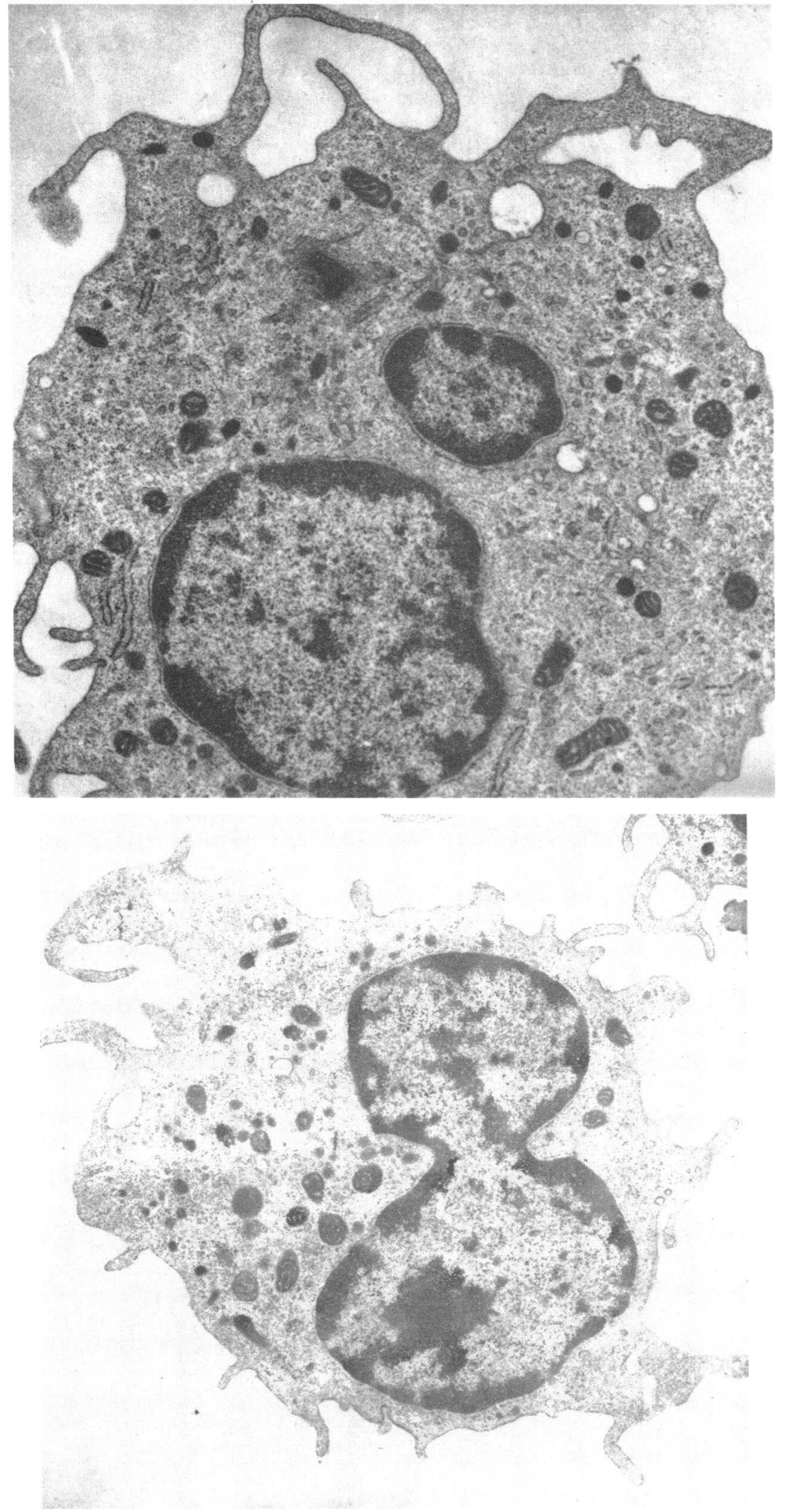

Figure 1. Ultrastructural morphology of monocytes. Cell suspensions $\left(0.7-1 \times 10^{7} / \mathrm{ml}\right)$ were fixed in $2.5 \%$ glutaraldehyde in $0.1 \mathrm{M}$ phosphate buffer, pH 7.3, and kept pelleted at $4^{\circ} \mathrm{C}$ until electron microscopy studies. Neither whole platelets nor fragments nor parts of membrane are observed surrounding the cell surface. increasing concentrations of ${ }^{125}$ I-fibrinogen (Fig. 3). A dose response curve was obtained with saturation at 5.80-7.35 $\times 10^{-7}$ $\mathrm{M}$ of added fibrinogen, with binding of $0.3 \pm 0.18 \mu \mathrm{g}$ of the radioligand bound $/ 10^{7}$ cells. Analysis of the binding data by the method of Scatchard (45) and Feldman (46) revealed two classes of receptors: $965-1,910$ high affinity fibrinogen binding sites $\left(K_{d}\right.$ $\left.=4-8 \times 10^{-9} \mathrm{M}\right)$ and $120,500-151,600$ low affinity fibrinogen binding sites $\left(K_{\mathrm{d}}=1.35-1.84 \times 10^{-6} \mathrm{M}\right)$ (Fig. 3). 


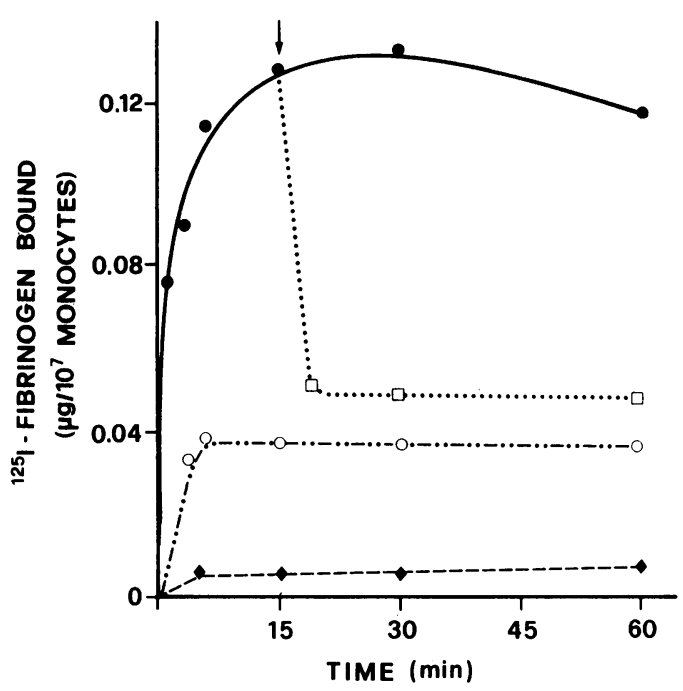

Figure 2. Time course of ${ }^{125}$ I-fibrinogen binding to thrombin-or ADPstimulated monocytes. For time course experiments (๑), suspensions of $1.5 \times 10^{7}$ monocytes $/ \mathrm{ml}$ were incubated with $1 \mathrm{U} / \mathrm{ml}$ thrombin or $10 \mu \mathrm{M}$ ADP for $1 \mathrm{~min}$ at room temperature in the presence of $1 \mathrm{mM}$ $\mathrm{CaCl}_{2}$. After addition of $5 \mathrm{U} / \mathrm{ml}$ hirudin, ${ }^{125} \mathrm{I}$-fibrinogen $\left(6 \times 10^{-8} \mathrm{M}\right)$ was added. At intervals, aliquots $(0.3 \mathrm{ml})$ of the mixture were centrifuged through silicone oil at $12,000 \mathrm{~g}$ for $2 \mathrm{~min}$ at room temperature to separate free and monocyte-bound fibrinogen. Nonspecific binding (o) was measured in the presence of $3 \times 10^{-6} \mathrm{M}$ of unlabeled fibrinogen and amounted to $30 \%$ of the maximum fibrinogen bound. Similar results were obtained after preincubation of the monocyte suspensions with $10 \mathrm{mM}$ EDTA. Experiments with unstimulated monocytes or thrombin- or ADP-stimulated lymphocytes were performed under the same experimental conditions ( $\bullet$ ). For displacement experiments ( $\square$ ), unlabeled fibrinogen $\left(3 \times 10^{-6} \mathrm{M}\right)$ was added at equilibrium (arrow) to ADP- or thrombin-stimulated monocytes and the incubations were terminated at different times, as described for the time course experiments.

Studies of the receptor involved in ${ }^{125}$ I-fibrinogen binding to monocytes. ${ }^{125}$ I-fibrinogen binding to stimulated monocytes was demonstrated to occur through a limited number of exposed specific receptors on the cell surface. To characterize these receptors better, we reinvestigated the problem of the existence of the GP IIb/IIIa complex on monocytes. Unstimulated or stimulated normal monocytes, exposed to increasing concentrations $(0.2-4.5 \mu \mathrm{g} / \mathrm{ml})$ of ${ }^{125} \mathrm{I}-10 \mathrm{E} 5$ antiplatelet GP IIb/IIIa complex monoclonal antibody, had a dose-dependent reaction, saturated when $2.24-3 \mu \mathrm{g} / \mathrm{ml}$ of antibody has been added. The Scatchard plot for these binding data was a straight line, suggesting a single class of receptors $\left(n=158,000 ; K_{d}=2.4 \times 10^{-8} \mathrm{M}\right.$ ) (Fig. 4). In contrast, ${ }^{125} \mathrm{I}-10 \mathrm{E} 5$ antibody binding to thrombasthenic monocytes was insignificant (Fig. 4). Thrombasthenic monocytes were subsequently tested for their ability to bind fibrinogen. After stimulation with ADP or thrombin there was no labeled fibrinogen binding to thrombasthenic cells (Fig. 5). In addition, preincubation of normal stimulated monocytes with $20 \mu \mathrm{g} / \mathrm{ml}$ of $10 \mathrm{E} 5$ antibody completely suppressed ${ }^{125}$ I-fibrinogen specific binding (Fig. 5). The fibrinogen receptor on the surface of normal monocytes was characterized by immunoprecipitation studies with 10E5 antibody. The antigen precipitated in the complex after interaction between 10E5 antibody and normal iodinated platelet or monocyte lysate was identified by SDS polyacrylamide gel electrophoresis followed by autoradiography. Normal reduced platelets treated with 10E5 antibody revealed two major radioactive bands, with 116,000 relative mol wt and 110,000 relative mol wt, in agreement with previous observations (40). In contrast, under the same experimental conditions, the monocyte surface component precipitated by $10 \mathrm{E} 5$ antibody migrated at a slightly different molecular weight, showing a major radioactive band with 92,000 relative mol wt and two other bands of 116,000 relative mol wt and 78,000 (Fig. 6). To confirm that the antigen precipitated by 10E5 antibody was of monocyte origin and actually synthesized during active cell metabolism, suspensions of monocytes were cultured in the presence of $\left[{ }^{35} S\right]$ methionine. Immunoprecipitation studies with $10 \mathrm{E} 5$ antibody conducted on metabolically labeled monocytes showed a pattern of radioactive bands migrating with the same mobility as the iodinated antigen (Fig. 6).

Data of several previous studies (48-51) indicate that the GP IIb/IIIa complex present on platelets is the receptor for fi-
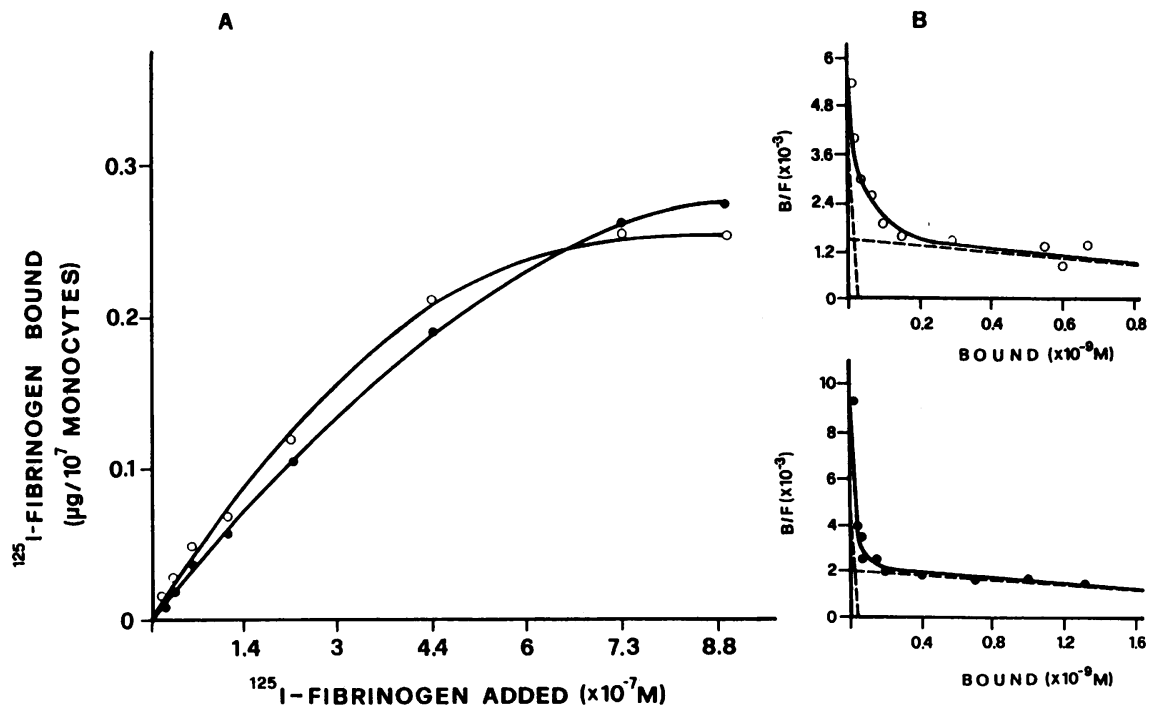

Figure 3. Specific binding of ${ }^{125}$ I-fibrinogen to stimulated monocytes. $(A)$ Increasing concentrations $\left(0.03-8.80 \times 10^{-7} \mathrm{M}\right)$ of ${ }^{125}$ I-fibrinogen were incubated for $15 \mathrm{~min}$ at room temperature with monocytes stimulated with 1 $\mathrm{U} / \mathrm{ml}$ thrombin (•) or $10 \mu \mathrm{M}$ ADP (o). The conditions of these experiments were the same as in Fig. 2. Concentrations of fibrinogen are final. The data are the means of five determinations. (B) All the values of ${ }^{125} \mathrm{I}-\mathrm{fi}-$ brinogen specific binding to monocytes represented in $(A)$ were plotted by the method of Scatchard (45) and analyzed by the method of Feldman (46). B, Monocyte bound ${ }^{125}$ I-fibrinogen; F, concentration of free labeled fibrinogen. - -, asymptotes of theoretical binding components; - , theoretical binding curves. Two classes of receptors are calculated: 965 high affinity $\left(K_{d}=4 \times 10^{-9} \mathrm{M}\right)$ and 151,600 low affinity receptors $\left(K_{d}=1.84 \times 10^{-6} \mathrm{M}\right)$ on thrombin-stimulated monocytes $(\bullet)$ and 1,910 high affinity $\left(K_{d}=8 \times 10^{-9} \mathrm{M}\right)$ and 120,500 low affinity receptors $\left(K_{d}=1.35 \times 10^{-6} \mathrm{M}\right)$ on ADP-stimulated monocytes $(0)$. 


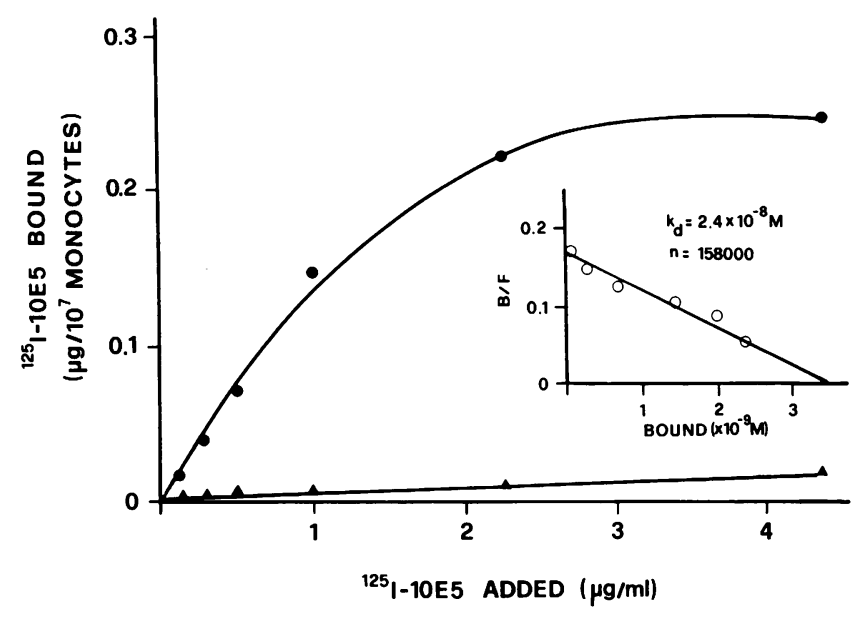

Figure 4. Specific binding of ${ }^{125} \mathrm{I}-10 \mathrm{E} 5$ antibody to normal or thrombasthenic monocytes. Suspensions of unstimulated or stimulated nor$\mathrm{mal}$ or thrombasthenic monocytes were incubated with increasing concentrations $(0.2-4.5 \mu \mathrm{g} / \mathrm{ml})$ of ${ }^{125} \mathrm{I}-10 \mathrm{E} 5$ antibody for $5 \mathrm{~min}$ at room temperature and in the presence of $1 \mathrm{mM} \mathrm{CaCl}_{2}$. Nonspecific ${ }^{125} \mathrm{I}-10 \mathrm{E} 5$ antibody binding was determined in the presence of a 50fold excess of unlabeled 10E5 antibody and amounted for $2 \%$ of the maximum binding. The binding assay was performed as described in Fig. 2. (•) normal monocytes. ( $\Delta$ ) thrombasthenic monocytes. The inset shows the Scatchard plot for the data of ${ }^{125} \mathrm{I}-10 \mathrm{E} 5$ antibody binding to normal monocytes. The data are the means of four experiments.

${ }^{125}$ I-10E5 antibody concentrations are final.

brinogen, fibronectin or vWF on the platelet surface. Therefore, further functional analysis of the receptor for fibrinogen on monocytes was carried out. To evaluate the possible interaction of other adhesive proteins such as fibronectin or vWF with monocytes, we studied the competitive inhibition by fibrinogen, fibronectin or VWF of ${ }^{125} \mathrm{I}$-fibrinogen binding to stimulated

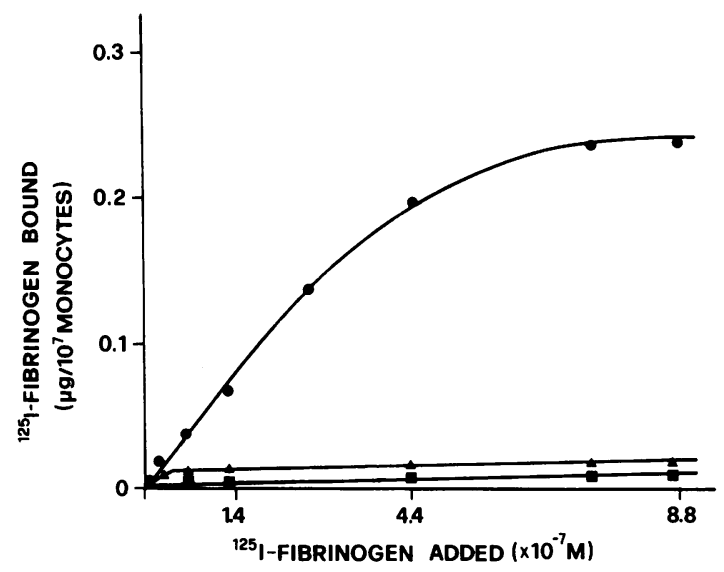

Figure 5. ${ }^{125}$ I-Fibrinogen binding to thrombasthenic monocytes or normal monocytes treated with $10 \mathrm{E} 5$ antibody. Suspensions of normal monocytes $(\bullet)$ or thrombasthenic monocytes $(\Delta)$ or normal monocytes preincubated with $20 \mu \mathrm{g} / \mathrm{ml}$ of $10 \mathrm{E} 5$ antibody ( $(\boldsymbol{)})$ were stimulated with $1 \mathrm{U} / \mathrm{ml}$ thrombin in the presence of $1 \mathrm{mM} \mathrm{CaCl}_{2}$. Increasing concentrations $\left(0.03-8.80 \times 10^{-7} \mathrm{M}\right)$ of ${ }^{125}$ I-fibrinogen were added and 15 min later fibrinogen binding was determined. The effect of $10 \mathrm{E} 5$ antibody was calculated on the ${ }^{125}$ I-fibrinogen specific binding to normal monocytes. Experimental conditions are the same as in Fig. 2. The data are the means of three experiments. Concentrations of ${ }^{125} \mathrm{I}$-fibrinogen are final.

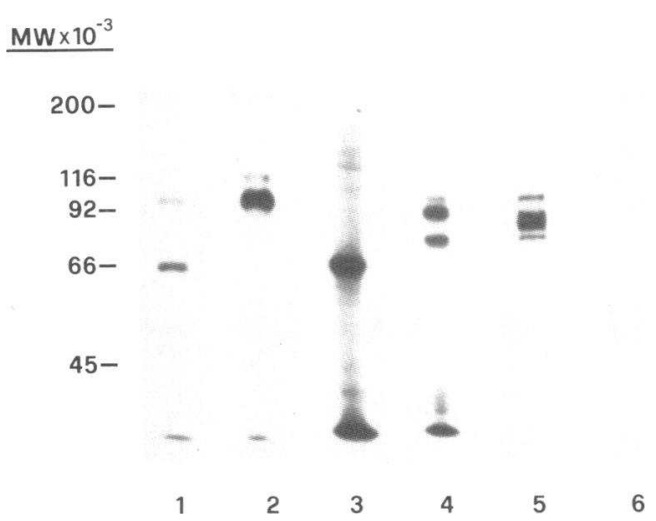

Figure 6. Autoradiography of SDS polyacrylamide gels of immunoprecipitates of surface labeled platelets and monocytes. Monocytes ( 7 $\left.\times 10^{7} / \mathrm{ml}\right)$ or washed platelets $\left(4 \times 10^{8} / \mathrm{ml}\right)$ were radiolabeled with ${ }^{125} \mathrm{I}$ by the Iodogen method and solubilized after incubation for $30 \mathrm{~min}$ at $4^{\circ} \mathrm{C}$ in lysis buffer containing $1 \%$ Nonidet $\mathrm{P}-40,0.5 \%$ Triton $\mathrm{X}-100$, $0.05 \mathrm{M}$ Tris- $\mathrm{HCl}, 0.15 \mathrm{M} \mathrm{NaCl}, 0.1 \% \mathrm{BSA}$, and $0.001 \mathrm{M}$ PMSF, pH 8.3. Aliquots of platelet or monocyte lysate were incubated with $10 \mathrm{E} 5$ antibody $(70 \mu \mathrm{g} / \mathrm{ml})$ for $18 \mathrm{~h}$ at $4^{\circ} \mathrm{C}$. Protein A Sepharose CL 4B $(25$ $\mu \mathrm{l}, 0.2 \mathrm{~g} / \mathrm{ml}$ ) was then added and the incubation was continued for $6 \mathrm{~h}$ at $4^{\circ} \mathrm{C}$. After exhaustive washing with $0.14 \mathrm{M}$ PBS, $\mathrm{pH} 7.4$, the pellet was resuspended in $0.06 \mathrm{M}$ Tris- $\mathrm{HCl}$ buffer containing $0.2 \mathrm{M}$ DTT and $3 \%$ SDS, pH 6.8. The samples were boiled, centrifuged at 12,000 $g$ for $5 \mathrm{~min}$ and run on $7.5 \%$ SDS polyacrylamide gel. Gels were fixed, stained, destained, dried, and exposed for autoradiography at $-70^{\circ} \mathrm{C}$ for $7 \mathrm{~d}$ using intensifying screens. Lanes 1 and 3 show the surface patterns of radiolabeled platelets and monocytes. Lane 2 was the immunoprecipitate of platelets, showing two major bands of 116,000 and 110,000 relative mol wt; lane 4 the immunoprecipitate of monocytes, consisting of one major band with a 92,000 relative mol wt and two other minor bands of 116,000 and 78,000 relative mol wt. Lane 5 contains the immunoprecipitate of metabolically labeled monocytes cultured in the presence of $\left[{ }^{35} \mathrm{~S}\right]$ methionine, showing the same antigen revealed by $10 \mathrm{E} 5$ antibody on ${ }^{125} \mathrm{I}$-labeled monocytes. Lane 6 , control immunoprecipitate of surface-labeled monocytes by normal IgG (70 $\mu \mathrm{g} / \mathrm{ml}$ ). Molecular weight standards are indicated on the left.

monocytes. Lineweaver-Burk double reciprocal plots of these data revealed that cold fibrinogen competitively inhibited labeled fibrinogen binding, while fibronectin or vWF did not interfere (Fig. 7). Furthermore, the direct interaction of ${ }^{125} \mathrm{I}-\mathrm{vWF}$ with thrombin-stimulated monocytes showed a non-specific and unsaturable association of the labeled protein (not shown).

$P C A$ expressed by human monocytes. The binding of fibrinogen to normal monocytes was related to the capacity of these cells to generate procoagulant material. Suspensions of normal monocytes stimulated with ADP to induce fibrinogen binding consistently shortened the normal human plasma recalcification time from that with unstimulated cells (Table I). Supernatants of stimulated monocytes, lymphocytes or platelets under the same experimental conditions did not have PCA. That fibrinogen binding to specific receptors on stimulated monocytes is directly associated with the PCA generation was further confirmed. In fact, suspensions of stimulated thrombasthenic monocytes or normal monocytes preincubated with $10 \mathrm{E} 5$ antibody at a concentration which totally blocks fibrinogen binding $(20 \mu \mathrm{g} / \mathrm{ml})$ had no PCA (Table I). ADP-stimulated normal monocytes equally shortened the recalcification times of Factor VII-, IX-, and XII-deficient plasmas. In contrast, cell PCA was abolished when plasma deficient in Factors $\mathrm{V}$ or $\mathrm{X}$ were tested. This sug- 


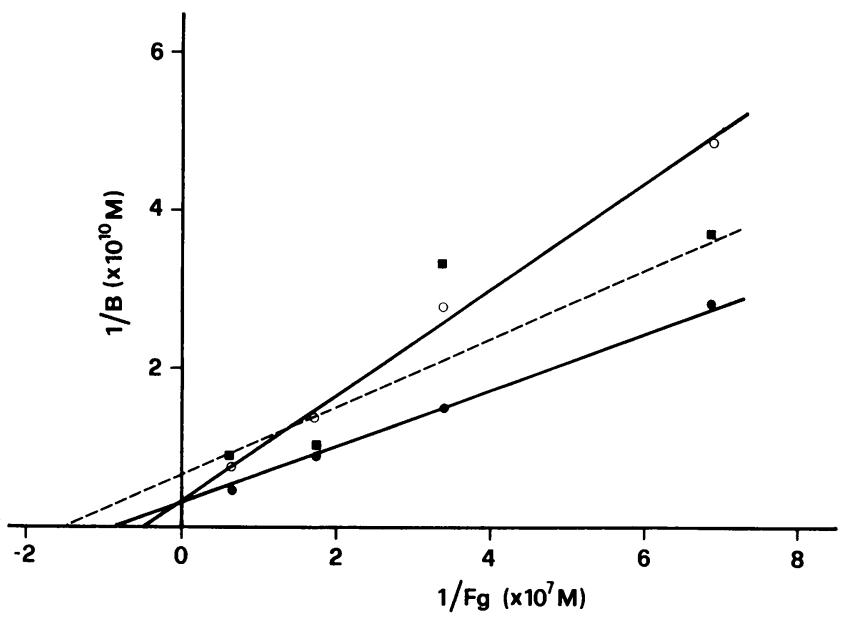

Figure 7. Competitive inhibition of ${ }^{125} \mathrm{I}$-fibrinogen binding to monocytes by cold fibrinogen. Aliquots $(0.2 \mathrm{ml})$ of monocytes stimulated with thrombin $(1 \mathrm{U} / \mathrm{ml})$ were incubated with ${ }^{125} \mathrm{I}$-fibrinogen (concentrations from 0.15 to $1.47 \times 10^{-7} \mathrm{M}$ ) in the presence of $7.3 \times 10^{-7} \mathrm{M}$ of cold fibrinogen or $250 \mu \mathrm{g} / \mathrm{ml}$ of vWF or fibronectin. The binding assay was performed as described in Fig. 2. The figure shows the Lineweaver-Burk double reciprocal plot for the data obtained in four separate similar experiments. $\mathbf{F g}$, concentrations of ${ }^{125}$ I-fibrinogen added; B, monocyte bound ${ }^{125}$ I-fibrinogen. The $y$-intercepts for labeled fibrin-

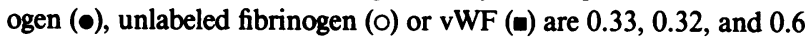
$\times 10^{10} \mathrm{M}$, respectively. When fibronectin was used as competing protein, the data did not give a straight line $(r=0.56)$ and the value of the relative $y$-intercept can not be calculated.

gests that only the common pathway of coagulation is involved in the monocyte PCA induced by fibrinogen binding (Table II).

\section{Discussion}

Conflicting data have recently been published about whether or not platelets and monocytes share the same receptor for fibrin-

Table I. PCA Generation by Human

Monocytes Stimulated with $10 \mu M$ ADP

\begin{tabular}{ll}
\hline & PCA \\
\hline & $U$ \\
Unstimulated monocytes (6)* & $0.98 \pm 0.32$ \\
Normal stimulated monocytes (6) & $40 \pm 6$ \\
10E5-treated stimulated monocytes (3) & $0.6 \pm 0.4$ \\
Thrombasthenic stimulated monocytes (3) & $1 \pm 0.4$ \\
Lymphocytes, platelets (3) & $0.12 \pm 0.025$ \\
RPMI 1640 medium & 0.1
\end{tabular}

Normal or thrombasthenic monocytes $\left(1.5 \times 10^{7} / \mathrm{ml}\right)$ were stimulated with ADP $(10 \mu \mathrm{M})$ for $10 \mathrm{~min}$ at room temperature in the presence of $1 \mathrm{mM} \mathrm{CaCl}_{2} .0 .1 \mathrm{ml}$ of the mixture was then incubated at $37^{\circ} \mathrm{C}$ with $0.1 \mathrm{ml}$ of normal plasma. At the end of $1 \mathrm{~min}$ incubation, $0.1 \mathrm{ml}$ of $0.025 \mathrm{M} \mathrm{CaCl}_{2}$ was added and the recalcification time recorded. $10 \mathrm{E} 5$ antiplatelet GP IIb/IIIa complex monoclonal antibody was incubated for $3 \mathrm{~min}$ at room temperature with monocytes before ADP-stimulation. Lymphocytes $\left(1.5 \times 10^{7} / \mathrm{ml}\right)$ or platelets $\left(4 \times 10^{8} / \mathrm{ml}\right)$ were tested for their ability to generate PCA under the experimental conditions described above. The data are means \pm SEM.

* No. of experiments.
Table II. Effects of Various Deficient Plasmas on PCA Generation by ADP-stimulated Monocytes

\begin{tabular}{ll}
\hline & PCA \\
\hline & \multicolumn{1}{l}{$U$} \\
Normal plasma (3)* & $32.5 \pm 1.5$ \\
Factor VII-deficient plasma (3) & $27.5 \pm 9.5$ \\
Factor XII-deficient plasma (3) & $21.5 \pm 4.5$ \\
Factor IX-deficient plasma (3) & $40.5 \pm 4.5$ \\
Factor X-deficient plasma (3) & $4.0 \pm 2.5$ \\
Factor V-deficient plasma (3) & $5.0 \pm 1.0$
\end{tabular}

Normal monocytes were incubated with $10 \mu \mathrm{M}$ ADP in the presence of $0.1 \mathrm{ml}$ of normal or various coagulation factor-deficient plasmas under the experimental conditions described in Table I. PCA generation by unstimulated monocytes was $1.12 \pm 0.8$. The data are means \pm SEM.

* No. of experiments.

ogen, the GP IIb/IIIa complex (24-28). Therefore, we decided to study whether or not human monocytes bind fibrinogen, and the problem of the existence of the GP IIb/IIIa complex on monocytes was addressed functionally.

Since platelet contaminants are the most insidious source of artifacts in monocyte studies (52), great efforts were applied to preparing platelet-free suspensions of monocytes. To do this, monocytes were processed by the method recommended by Pawlowski et al. (31) for removing platelets adhering to monocytes. Several means were used to determine the purity of the monocyte preparations. Aliquots of washed iodinated platelets were added to the whole blood before starting the cell isolation procedures. Since $<0.1 \%$ of the platelet radioactivity was found in the last monocyte suspension, we calculated an average of $<4$ platelets per 100 monocytes to be present in our cell preparations. Even in the presence of similar levels of added platelet contamination (5\%), we observed that the interaction of fibrinogen with monocytes was unchanged. Furthermore, we added aliquots of normal platelets to the whole blood of a patient with thrombasthenia. There was complete removal of these platelets by the washing techniques, because no ${ }^{125} \mathrm{I}$-fibrinogen binding was observed in these suspensions of thrombasthenic monocytes. Finally, careful examination of several monocyte preparations by electron microscopy confirmed that they contained no free platelets or platelet fragments on the monocyte surfaces.

Under these experimental conditions, we have shown that normal human monocytes stimulated with thrombin or ADP specifically bind ${ }^{125} \mathrm{I}$-fibrinogen. This reaction is optimal at both room temperature and at $37^{\circ} \mathrm{C}$, it is saturated and calculation from the binding data plotted by the method of Scatchard (45) and analyzed by the method of Feldman (46) revealed two different classes of receptors on the cell surface. We attempted to characterize these receptors, looking for similarities with the platelet GP IIb/IIIa complex, first, because ${ }^{125}$ I-fibrinogen binding to stimulated platelets is well known to occur through the availability of the GP IIb/IIIa complex (18-23) and, second, because the presence of the GP IIb/IIIa complex on monocytes, although postulated (24-26), is controversial $(27,28)$. We established that thrombasthenic monocytes do not react with labeled 10E5 antibody antiplatelet GP IIb/IIIa complex. This suggests that the antigen recognized by this antibody is not available on the surface 
of these cells. In contrast, normal monocytes bound labeled 10E5 antibody in a saturated reaction. The number of binding sites revealed on normal monocytes by $10 \mathrm{E} 5$ antibody $(n=158,000)$ was very similar to the number of sites exposed on these cells when fibrinogen binding was induced (965-1,910 high affinity sites and 120,500-151,600 low affinity sites). In addition there was no ${ }^{125} \mathrm{I}$-fibrinogen binding to thrombasthenic monocytes and normal monocytes treated with 10E5 antibody became unable to bind fibrinogen.

The fibrinogen receptor on normal monocytes was identified with 10E5 antibody. Metabolic studies conducted on cultured monocytes in the presence of $\left[{ }^{35} \mathrm{~S}\right]$ methionine demonstrated that the surface antigen recognized by $10 \mathrm{E} 5$ antibody is synthesized as a genuine product of cell metabolism. The pattern of the monocyte surface component precipitated by $10 \mathrm{E} 5$ antibody on normal monocytes furthermore, showed it to have a lower molecular weight than that of the GP IIb/IIIa complex recognized by the same antibody on normal platelets. We further investigated the functional aspects of the receptor for fibrinogen on monocytes. It was found that the interactions of this receptor with other adhesive proteins such as fibronectin or vWF, were completely different from that with the platelet GP IIb/IIIa complex (48-51). In fact, neither vWF nor fibronectin competitively inhibited fibrinogen binding to monocytes and, furthermore, no specific binding of ${ }^{125} \mathrm{I}-\mathrm{vWF}$ to stimulated monocytes was observed.

Taken together, these observations, plus the fact that the number of fibrinogen binding sites on monocytes is different from the number of sites on platelets $(18,19,21-23)$ suggest that there are important differences between the receptor for fibrinogen on monocytes and the platelet GP IIb/IIIa complex. It appears even more unlikely that undetectable platelet contamination thus was responsible for our findings. Moreover, we suggest that these important differences might explain the discrepancies in the literature about the existence of the GP IIb/ IIIa complex on monocytes (24-28). In fact, all previous studies were based only on the different reactivity of antiplatelet antibodies with monocytes. The differences between the fibrinogen receptor on monocytes and the platelet GP IIb/IIIa complex make it possible that only a few epitopes of these two antigens are identical. Consequently, not all antiplatelet antibodies need necessarily react with monocytes. For this reason, polyclonal antibodies such as those used by Clemetson et al. (27) and by Levene and Rabellino (28), because their specificity is lower than that of monoclonal antibodies used by others $(24,25,53)$, are less able to identify a monocyte surface component that is similar to but not identical with the platelet GP IIb/IIIa complex. We affirm that some surface antigen, at least in part functionally related to the platelet GP IIb/IIIa complex, therefore, is required for fibrinogen binding to monocytes.

The concept of a direct interaction of fibrinogen with monocytes appears to be further inforced by the recent observation that mouse peritoneal macrophages specifically bind fibrinogen degradation products (54). Receptors for the D-domain of fibrinogen, only in part functionally related to the platelet GP IIb/IIIa complex have been described on the surface of these cells (54). The binding of fibrinogen to stimulated platelets is required for aggregation (18-23) and we have shown that the binding of fibrinogen to monocytes greatly enhances the PCA of these cells. In fact, neither normal monocytes preincubated with 10E5 antibody nor thrombasthenic cells bound fibrinogen and had no PCA. Monocyte PCA can be distinguished by its expression after a very short incubation with a particular stimulus (ADP) and by its requirements for Factors X and V. Moreover, monocyte PCA could not be detected in the supernatants of ADP-stimulated cells. Taken together, these observations suggest that under our experimental conditions, rather than being a thromboplastin-like material (6-10), monocyte PCA is membrane-bound and completely independent of the extrinsic or intrinsic coagulation pathway. Therefore the binding of fibrinogen to specific receptors on monocytes appears to be a membrane signal triggering an enzyme-like activity that induces rapid deposition of fibrin on the cell surface.

In conclusion, our data suggest that several stimuli and multiple interactions regulate the PCA expressed by monocytes. Moreover, Glanzmann's thrombasthenia appears to be a congenital disorder with several defects of the hemostatic process. The findings described here, while they demonstrate a specific interaction between monocytes and fibrinogen, also emphasize the concept that coagulation and inflammation are interdependent and closely related processes.

\section{Acknowledgments}

We wish to thank Dr. Matteo Russo for the electron microscopy studies, Dr. Augusto B. Federici for kindly providing purified human vWF, Dr. B. S. Coller for 10E5 antibody, and Dr. Cutolo for purified fibronectin. Dr. Enrico Rovati revised the analysis of the data for ${ }^{125}$ I-fibrinogen binding.

\section{References}

1. Gordon, S., and Z. A. Cohn. 1973. The macrophage. Int. Rev. Cytol. 36:171-214.

2. Rosenthal, A. S., M. A. Bacinski, and L. J. Rosenwasser. 1978. Functions of macrophages in genetic control of immune responsiveness. Fed. Proc. 37:79-85.

3. Doherty, P. C., and R. M. Zinkernagel. 1976. Lymphocyte-macrophage interactions in the expression of antimicrobial immunity in vivo. In Immunobiology of the macrophage. D. S. Nelson, editor. Academic Press, Inc., New York. 367-420.

4. Raff, H. V., L. J. Picker, and J. D. Stobo. 1980. Macrophage heterogeneity in man. A subpopulation of HLA-DR-bearing macrophages required for antigen induced T-cell activation also contains stimulators for autologous-reactive T cells. J. Exp. Med. 152:581-593.

5. Freundlich, B., G. Trinchieri, B. Perussia, and R. B. Zurier. 1984. The cytotoxic effector cells in preparations of adherent mononuclear cells from human peripheral blood. J. Immunol. 132:1255-1260.

6. Rivers, R. P. A., W. E. Hathaway, and W. L. Weston. 1975. The endotoxin-induced coagulant activity of human monocytes. Br. J. Haematol. 30:311-316.

7. Edwards, R. L., F. R. Rickles, and A. M. Bobrove. 1979. Mononuclear cell tissue factor: cell of origin and requirements for activation. Blood. 54:359-370.

8. Rothberger, H., T. S. Zimmerman, H. L. Spiegelberg, and J. H. Vaughan. 1977. Leukocyte procoagulant activity enhancement of production in vitro by IgG and antigen-antibody complexes. J. Clin. Invest. 59:549-557.

9. Muhlfelder, T. W., J. Niemetz, D. Kreutzer, D. Beebe, P. Ward, and S. I. Rosenfeld. 1979. C5 chemotactic fragment induces leukocyte production of tissue factor activity. J. Clin. Invest. 63:147-150.

10. Rothberger, H., T. S. Zimmerman, and J. H. Vaughan. 1978. Increased production and expression of tissue thromboplastin-like procoagulant activity in vitro by allogeneically stimulated human leukocytes. J. Clin. Invest. 62:649-655.

11. Levy, G. A., B. S. Schwartz, L. K. Curtiss, and T. S. Edgington. 1981. Plasma lipoprotein induction and suppression of the generation of cellular procoagulant activity in vitro. Requirements for cellular collaboration. J. Clin. Invest. 67:1614-1622. 
12. Broze, G. J. 1982. Binding of human Factor VII and VIIa to monocytes. J. Clin. Invest. 70:526-535.

13. Colvin, R. B., and H. F. Dvorak. 1975. Fibrinogen/fibrin on the surface of macrophages: detection, distribution, binding requirements and possible role in macrophage adherence phenomena. J. Exp. Med. 142:1377-1390.

14. Hogg, N. 1983. Human monocytes are associated with the formation of fibrin. J. Exp. Med. 157:473-485.

15. Sherman, L. A., and J. Lee. 1977. Specific binding of soluble fibrin to macrophages. J. Exp. Med. 145:76-85.

16. Alitalo, K., T. Hovi, and A. Vaheri. 1980. Fibronectin is produced by human macrophages. J. Exp. Med. 151:602-613.

17. Jaffe, E. A., J. T. Ruggiero, and D. J. Falcone. 1985. Monocytes and macrophages synthesize and secrete thrombospondin. Blood. 65 : 79-84.

18. Marguerie, G. A., E. F. Plow, and T. S. Edgington. 1979. Human platelets possess an inducible and saturable receptor specific for fibrinogen. J. Biol. Chem. 54:5357-5363.

19. Bennett, J. S., and G. Vilaire. 1979. Exposure of platelet fibrinogen receptors by ADP and epinephrine. J. Clin. Invest. 64:1393-1401.

20. Mustard, J. F., R. L. Kinlough-Rathbone, M. A. Packham, D. W. Perry, E. J. Harfenist, and K. R. M. Pai. 1979. Comparison of fibrinogen association with normal and thrombasthenic platelets on exposure to ADP or chymotrypsin. Blood. 54:987-993.

21. Di Minno, G., P. Thiagarajan, B. Perussia, J. Martinez, S. Shapiro, G. Trinchieri, and S. Murphy. 1983. Exposure of platelet fibrinogenbinding sites by collagen, arachidonic acid and ADP. Inhibition by a monoclonal antibody to the glycoprotein IIb-IIIa complex. Blood. 61: 140-148.

22. Peerschke, E. I., M. B. Zucker, R. A. Grant, J. J. Egan, and M. M. Johnson. 1980. Correlation between fibrinogen binding to human platelets and platelet aggregability. Blood. 55:841-847.

23. Niewiarowski, S., A. Z. Budzynski, T. A. Morinelli, T. M. Brudzynski, and G. J. Stewart. 1981. Exposure of fibrinogen receptor on human platelets by proteolytic enzymes. J. Biol. Chem. 256:917-925.

24. Burckhardt, J. J., W. H. Kerr Anderson, J. F. Kearney, and M. D. Cooper. 1982. Human blood monocytes and platelets share a cell surface component. Blood. 60:767-771.

25. Bai, Y., H. Durbin, and N. Hogg. 1984. Monoclonal antibodies specific for platelet glycoproteins react with human monocytes. Blood. 64:139-146.

26. Gogstad, G., O. Hetland, N. O. Solum, and H. Prydz. 1983. Monocytes and platelets share the glycoproteins IIb and IIIa that are absent from both cells in Glanzmann's thrombasthenia type 1. Biochem. J. 214:331-337.

27. Clemetson, K. J., J. L. McGregor, R. P. McEver, Y. V. Jacques, D. F. Bainton, W. Domzig, and M. Baggiolini. 1985. Absence of platelet membrane glycoproteins IIb/IIIa from monocytes. J. Exp. Med. 161: 972-983.

28. Levene, R. B., and E. M. Rabellino. 1986. Platelet glycoproteins IIb and IIIa associated with blood monocytes are derived from platelets. Blood. 67:207-213.

29. Molnar, J., and L. Lorand. 1961. Studies on apyrases. Arch. Biochem. Biophys. 93:353-363.

30. Bøyum, A. 1968. Isolation of mononuclear cells and granulocytes from human blood. Scand. J. Clin. Lab. Invest. 21(Suppl. 97):77-89.

31. Pawlowski, N. A., G. Kaplan, A. L. Hamill, Z. A. Cohn, and W. A. Scott. 1983. Arachidonic acid metabolism by human monocytes. J. Exp. Med. 158:393-412.

32. Fischer, D. G., and H. S. Koren. 1981. Methods for studying mononuclear phagocytes. Academic Press, Inc., New York. 43-47.

33. Clemetson, K. J., A. M. Capitanio, F. I. Pareti, J. L. McGregor, and E. F. Luscher. 1980. Additional platelet membrane glycoprotein abnormalities in Glanzmann's thrombasthenia: a comparison with normals by high resolution two-dimensional polyacrylamide gel electrophoresis. Thromb. Res. 18:797-806.

34. McGregor, J. L., K. J. Clemetson, E. James, A. M. Capitanio, T. Greenland, E. F. Luscher, and M. Dechavanne. 1981. Glycoproteins of platelet membranes from Glanzmann's thrombasthenia. Eur. J. Biochem. 116:379-388.

35. Mustard, J. F., D. W. Perry, N. G. Ardlie, and M. A. Packham. 1972. Preparation of suspensions of washed platelets from humans. $\mathrm{Br}$ J. Haematol. 22:193-204.

36. Tuszynski, G. P., L. C. Knight, E. Kornecki, and S. Srivastava 1983. Labeling of platelet surface proteins with ${ }^{125} \mathrm{I}$ by the Iodogen method. Anal. Biochem. 130:166-170.

37. Kazal, L. A., S. Amsel, O. P. Miller, and L. M. Tocantins. 1963. The preparation and some properties of fibrinogen precipitated from human plasma by glycine. Proc. Soc. Exp. Biol. Med. 113:989-994.

38. Fraker, P. J., and J. C. Speck, Jr. 1978. Protein and cell membrane iodinations with a sparingly soluble chloroamine, 1,3,4,6-tetrachloro3a,6a-diphenylglycoluril. Biochem. Biophys. Res. Commun. 80:849-857.

39. De Marco, L., and S. S. Shapiro. 1981. Properties of human asialo-Factor VIII. A ristocetin-independent platelet-aggregating agent. J. Clin. Invest. 68:321-328.

40. Coller, B. S., E. I., Peerschke, L. E. Scudder, and C. A. Sullivan. 1983. A murine monoclonal antibody that completely blocks the binding of fibrinogen to platelets produces a thrombasthenic-like state in normal platelets and binds to glycoproteins IIb and/or IIIa. J. Clin. Invest. 72: 325-338.

41. Greenwood, F. C., W. M. Hunter, and J. S. Glover. 1963. The preparation of ${ }^{131}$ I-labelled human growth hormone of high specific radioactivity. Biochem. J. 89:114-123.

42. Di Minno, G., F. Coraggio, A. M. Cerbone, A. M. Capitanio, C Manzo, M. Spina, P. Scarpato, G. M. R. Dattoli, P. L. Mattioli, and M. Mancini. 1986. A myeloma paraprotein with specificity for platelet glycoprotein IIIa in a patient with a fatal bleeding disorder. J. Clin. Invest. $77: 157-164$.

43. Laemmli, U. K. 1970. Cleavage of structural proteins during the assembly of the head of bacteriophage $T_{4}$. Nature (Lond.). 227:680-685.

44. Kornberg, A., A. Treves, E. A. Rachmilewitz, and E. Fibach. 1983. Generation of procoagulant activity (PCA) by macrophage-like cells derived from acute and chronic myeloid leukaemia cells in response to phorbol esters. Scand. J. Haematol. 31:102-108.

45. Scatchard, G. 1949. The attraction of proteins for small molecules and ions. Ann. NY Acad. Sci. 51:660-672.

46. Feldman, H. A. Mathematical theory of complex ligand-binding system at equilibrium. Anal. Biochem. 130:317-338.

47. Tallarida, R. J., and R. B. Murray. 1981. Manual of Pharmacologic Calculations. Springer-Verlag, New York. 35-39.

48. Ruggeri, Z. M., R. Bader, and L. De Marco. 1982. Glanzmann thrombasthenia: deficient binding of von Willebrand factor to thrombinstimulated platelets. Proc. Natl. Acad. Sci. USA. 79:6038-6041.

49. Plow, E. F., A. H. Srouji, D. Meyer, G. Marguerie, and M. H. Ginsberg. 1984. Evidence that three adhesive proteins interact with a common recognition site on activated platelets. J. Biol. Chem. 259:53885391.

50. Plow, E. F., and M. H. Ginsberg. 1981. Specific and saturable binding of plasma fibronectin to thrombin-stimulated human platelets. J. Biol. Chem. 256:9477-9482.

51. Gralnick, H. R., S. B. Williams, and B. S. Coller. 1984. Fibrinogen competes with von Willebrand factor for binding to the glycoprotein IIb/IIIa complex when platelets are stimulated with thrombin. Blood. 64:797-800

52. Perussia, B., J. Jankiewicz, and G. Trinchieri. 1982. Binding of platelets to human monocytes: a source of artifacts in the study of the specificity of antileukocyte antibodies. J. Immunol. Methods. 50:269276.

53. Newman, P. J., R. W. Allen, S. T. Roodman, T. J. Kunicki, and R. Kahn. 1983. A monoclonal antibody specific for human platelet membrane glycoprotein IIIa binds to monocytes and neutrophils. Blood. 62(Suppl.):263. (Abstr.)

54. Rajogopalan, S., and S. V. Pizzo. 1986. Characterization of murine peritoneal macrophage receptors for fibrin(ogen) degradation products. Blood. 67:1224-1228. 